\title{
CARBONATITES OF K-ALKALINE COMPLEXES OF THE ALDAN, NORTH PAMIR AND SOUTH MONGOLIA.
}

Vladykin N.V.

Institute of Geochemistry, Irkutsk, USSR.

The calcite, calcite-fluorite and $\mathrm{Ba}-\mathrm{Sr}$ carbonatites are found in the complicated laminated complexes of $\mathrm{K}$-alkaline rocks. The carbonatites of the South Mongolia, Aldan (Murun, Khani, Arbarastakh, Intili massifs) as well as of North Pamir (Darai-Pioz) were studied. The complexes are composed of K-ultramafic rocks (Btpyroxenites, K-ijolites, melanephelinite) leucite and alkaline syenites, alkaline granites.

In the Murun and Darai-Pioz massifs the carbonatites are intruded after the alkaline granites, trey possess the unique mineral composition. Among the rare minerals, charoite, tinansite, pectolites, mizerite, agrellite, ekanite, dalyite are available here. The marked variations of the chemical and rare-element composition is typical of carbonatites. Nb, TR, Ba, Sf, P occurrences are known. The studied carbonatites were formed from the residual melt. It is confirmed by the presence of the molten inclusions and $\mathrm{Ba}-\mathrm{Sr}$ carbonatite disintegration. 